\title{
A CLINICO-EPIDEMIOLOGICAL STUDY OF BITES BY SPIDERS OF THE GENUS Phoneutria
}

\author{
Fábio BUCARETCHI(1,6), Cláudia Regina de DEUS REINALDO(2), Stephen HYSLOP(3,6), Paulo Roberto MADUREIRA(4,6),
} Eduardo Mello DE CAPITANI $(5,6)$ \& Ronan José VIEIRA(5,6)

\begin{abstract}
SUMMARY
From January, 1984 to December, 1996, 422 patients (ages 9 m-99 y, median 29 y) were admitted after being bitten by spiders which were brought and identified as Phoneutria spp. Most of the bites occurred at March and April months (29.2\%), in the houses (54.5\%), during the day (76.5\%), and in the limbs (feet 40.9\%, hands 34.3\%). Upon hospital admission, most patients presented only local complaints, mainly pain $(92.1 \%)$ and edema $(33.1 \%)$ and were classified as presenting mild $(89.8 \%)$, moderate $(8.5 \%)$ and severe $(0.5 \%)$ envenomation. Few patients $(1.2 \%)$ did not present signs of envenomation. Severe accidents were only confirmed in two children $(9 \mathrm{~m}, 3 \mathrm{y})$. Both developed acute pulmonary edema, and the older died $9 \mathrm{~h}$ after the accident. Patients more than 70 yearold had a significantly greater $(\mathrm{p}<0.05)$ frequency of moderate envenomations compared to the $10-70$-year-old individuals. Proceedings to relief local pain were frequently performed (local anesthesia alone $32.0 \%$, local anesthesia plus analgesics $20.6 \%$ and oral analgesics alone $25.1 \%$ ). Only $2.3 \%$ of the patients (two cases classified as severe and eight as moderate, eight of them in children) were treated with i.v. antiarachnid antivenom. No antivenom early reaction was observed. In conclusion, accidents involving the genus Phoneutria are common in the region of Campinas, with the highest risk groups being children under 10 years of age and adults over 70 years of age. Cases of serious envenomation are rare $(0.5 \%)$.
\end{abstract}

KEYWORDS: Phoneutria spp.; Spider envenomation.

\section{INTRODUCTION}

Spiders of the genus Phoneutria, popularly known as "armed" spiders or banana spiders are restricted to South America. Most of the clinically important accidents involving this genus occur in Brazil where there are four main species: P. fera and P. reidyi, found in the Amazon region, and $P$. keyserlingi and $P$. nigriventer, which occur in the central-western, southeastern and southern parts of the country. Of these four species, the latter is the most important cause of envenomations ${ }^{11,14}$.

According to the Brazilian Ministry of Health, Phoneutria spp. are the second most important cause of spider bites in this country ${ }^{14}$. From 1990 to 1993, bites by Phoneutria spp. accounted for $42.2 \%$ of the 11,392 accidents involving spiders in which the genus was known or suspected. Most of these accidents occurred in southern (39.7\%) and southeastern $(60 \%)$ Brazil $^{14}$.

Despite the medical importance of this genus, few studies have investigated the clinical and epidemiological aspects of envenomation by Phoneutria $\mathrm{spp}^{3,4}$. In the present report, we provide a retrospective study of envenomations involving this genus.

\section{PATIENTS AND METHODS}

The hospital records of 421 patients attended by the Poison Control Center in the university teaching hospital at the State University of Campinas (UNICAMP) over a 13 year period (January 1984 - December 1996) were analyzed retrospectively. An additional patient, a 9-monthold child who suffered severe envenomation, followed by our Poison Control Center and treated at the university hospital of the Pontifical Catholic University of Campinas, was also included in the study group. In all cases, the offending spider was identified as belonging to the genus Phoneutria.

In all cases, information on the time, day and month of envenomation as well as the patient's age, sex and geographic residence were recorded. The place where the bite occurred as well as the anatomic site of the bite, the application of first aid, time elapsed between the bite and medical treatment, the local and systemic signs and symptoms observed, the classification of the severity of the envenomation, the treatment administered upon admission, the number of local infiltrations of anesthetic, the number of ampoules of antiarachnid antivenom and any early reactions to antivenom as well as the subsequent outcome of the 
cases were noted. These data were analyzed using the software program Epi-Info version 6.02 produced by the Center for Diseases Control (Atlanta, GA, USA).

The accidents were classified as asymptomatic when the patient presented no local or systemic manifestations, mild when there was pain and other local manifestations eventually associated with tachycardia and restless, moderate when, in addition to the above manifestations there was sweating and/or occasional vomiting, and severe when the responses above were associated with profuse sweating, frequent vomiting, muscle hypertonia, priapism, shock and/or acute pulmonary edema $^{13}$. In most cases, there was insufficient information to allow the inclusion of arterial hypertension or hypotension as an important manifestation in the above responses.

When required, heterologous commercial equine antiarachnid antivenom ( $5 \mathrm{ml} /$ ampoule) produced by the Instituto Butantan (São Paulo, $\mathrm{SP}$ ) was administered i.v. over 5-20 min without prior medication. One milliliter of this antivenom, which consists mainly of the $\mathrm{F}(\mathrm{ab})_{2}$, fragment of immunoglobulins, neutralizes 7.5 minimum lethal doses of $P$. nigriventer reference venom in guinea-pigs.

Differences between the frequencies of the group of accidents classified as asymptomatic and mild and those group classified as moderate and severe, in three different age subgroups ( $<10 \mathrm{y}, 10-70 \mathrm{y}$ or $>70 \mathrm{y}$ ), were compared using the chi-square and Fisher exact tests. A $\mathrm{p}$ value $<0.05$ was considered to indicate significance.

\section{RESULTS}

Bites by Phoneutria spp. were most common in March and April and least common in September and October (Figure 1). Most cases involved male victims $(66.6 \%)$ and occurred during the day $(76.5 \%)$ in the home $(54.5 \%)$ or during work activities $(13.3 \%)$.

Limbs were the most common anatomic site of bites with $40.9 \%$ involving the feet and $34.3 \%$ the hands. Most clinical manifestations were local (Figure 2), with pain being the most common complaint (92.1\%) at presentation. Most victims (73.2\%) sought medical assistance within $4 \mathrm{~h}$ of the bite. The most frequent systemic manifestations observed in the group of patients classified as moderate and severe $(\mathrm{N}=38)$ were: sweating $(\mathrm{N}=14)$, tachycardia $(\mathrm{N}=8)$, prostration $(\mathrm{N}=5)$, vomiting $(\mathrm{N}=5)$, tachypnea $(\mathrm{N}=4)$, bradypnea $(\mathrm{N}=4)$, pallor $(\mathrm{N}=4)$, cyanosis $(\mathrm{N}=4)$ and diarrhea $(\mathrm{N}=3)$.

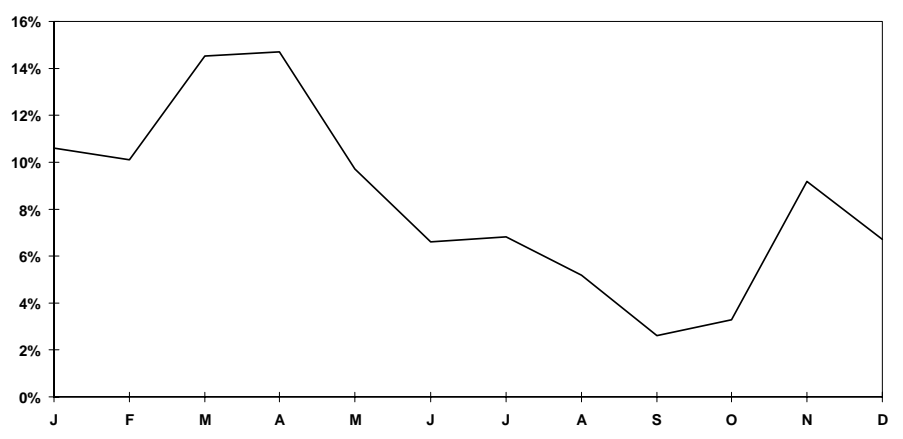

Fig 1 - Seasonal distribution of bites by Phoneutria spp.
The patients' age ranged from 9 months to 99 years (median, 29 years). Patients more than 70 year-old had a significantly greater $(p<0.05)$ frequency of moderate envenomations compared to the 10-70-year-old individuals whereas there was no difference between children $<10$ yearold and the other two groups (Figure 3). Only two cases (one child 9 months old and another 3 year-old), admitted $2 \mathrm{~h}$ and $3 \mathrm{~h}$, respectively after the accident, were classified as severe and resulted in death of the older $9 \mathrm{~h}$ after the bite following acute pulmonary edema. Table 1 summarizes the main clinical features in these two cases.

Therapeutic approaches to treat local pain were employed in 328 $(84.3 \%)$ of the 389 patients with this complaint. Local anesthesia alone $(41.1 \%)$, local anesthesia plus analgesics $(26.6 \%)$ and oral analgesics alone $(32.3 \%)$ were used in the above cases. Most patients treated with local anesthesia requiring only one such intervention (72.0\%). Analgesics were not prescribed upon admission if the cases were classified as asymptomatic $(1.2 \%)$ or if the pain had ameliorated or was considered mild and tolerable. Antivenom was used in only $2.3 \%$ of the cases ( 2 severe and 8 moderate envenomations, requiring 20-50 $\mathrm{ml}-$ median of $25 \mathrm{ml}$ ). Of these 10 cases, only two of the patients were more than 10 year-old (54 and 63 years). None of the patients developed any early reaction to the antivenom.

\section{DISCUSSION}

Although Phoneutria spp. are essentially wandering, nocturnal spiders, most accidents in the above series of patients occurred during the day mainly in urban homes, thus indicating that these spiders readily adapt to new environments ${ }^{6,11,14-15}$. These accidents are more common in March and April and are probably related to the mating season of these spiders when they are more easily seen and captured ${ }^{15}$.

Phoneutria spp. are commonly encountered in shoes, bundles of sticks, among rubbish and construction materials as well as in banana bunches $^{6,11,14-15}$, which could partly explain the greater frequency of bites

Table 1

Clinical manifestations upon admission in two children following serious envenomation by Phoneutria spp.

\begin{tabular}{lcc}
\hline $\begin{array}{l}\text { Clinical manifestations } \\
\text { and treatment }\end{array}$ & $\begin{array}{c}\text { Patient } 1 *, \\
\text { 3-year-old, } \\
\text { female, 1985 }\end{array}$ & $\begin{array}{c}\text { Patient 2, } \\
\text { 9-month-old, } \\
\text { male, } 1996\end{array}$ \\
\hline Local pain & + & + \\
Tachycardia & + & + \\
Prostration & + & + \\
Profuse sweating & + & - \\
Poor peripheral perfusion & - & + \\
Muscle fasciculation & - & + \\
Diarrhea & + & - \\
Vomiting & + & - \\
Priapism & - & + \\
Pulmonary edema & + & + \\
Mechanical ventilation & - & $25 \mathrm{ml}, 6 \mathrm{~h} \mathrm{pb}$ \\
Antivenom & $50 \mathrm{ml}, 3 \mathrm{~h} \mathrm{pb}$ &
\end{tabular}

Legends: $+=$ present, $-=$ absent, $\mathrm{h}=$ hours, $\mathrm{pb}=$ post-bite, ${ }^{*}=$ death 6 hours post-bite. 


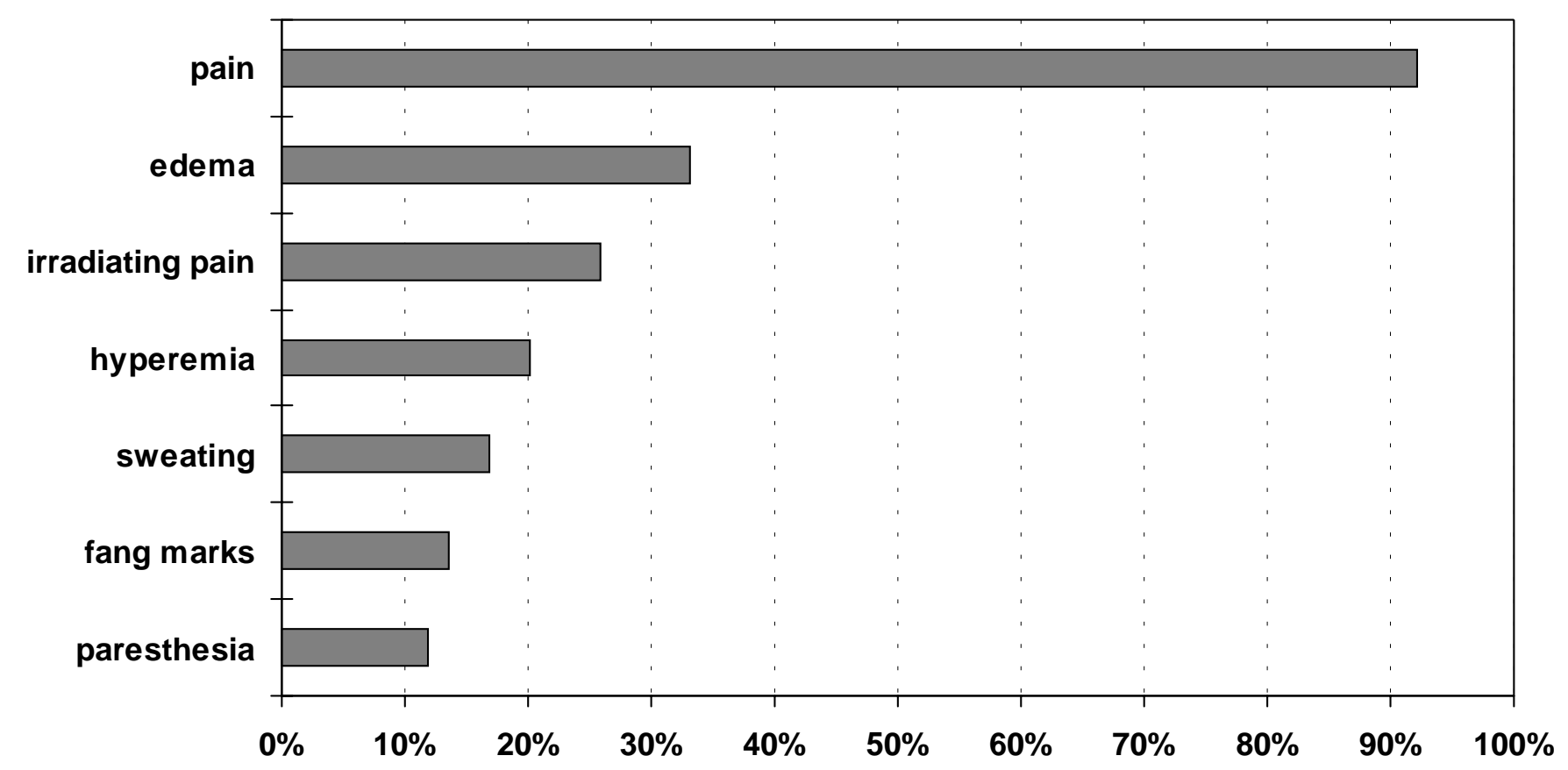

Fig 2 - Main local clinical manifestations upon admissions in 422 patients bitten by Phoneutria spp.

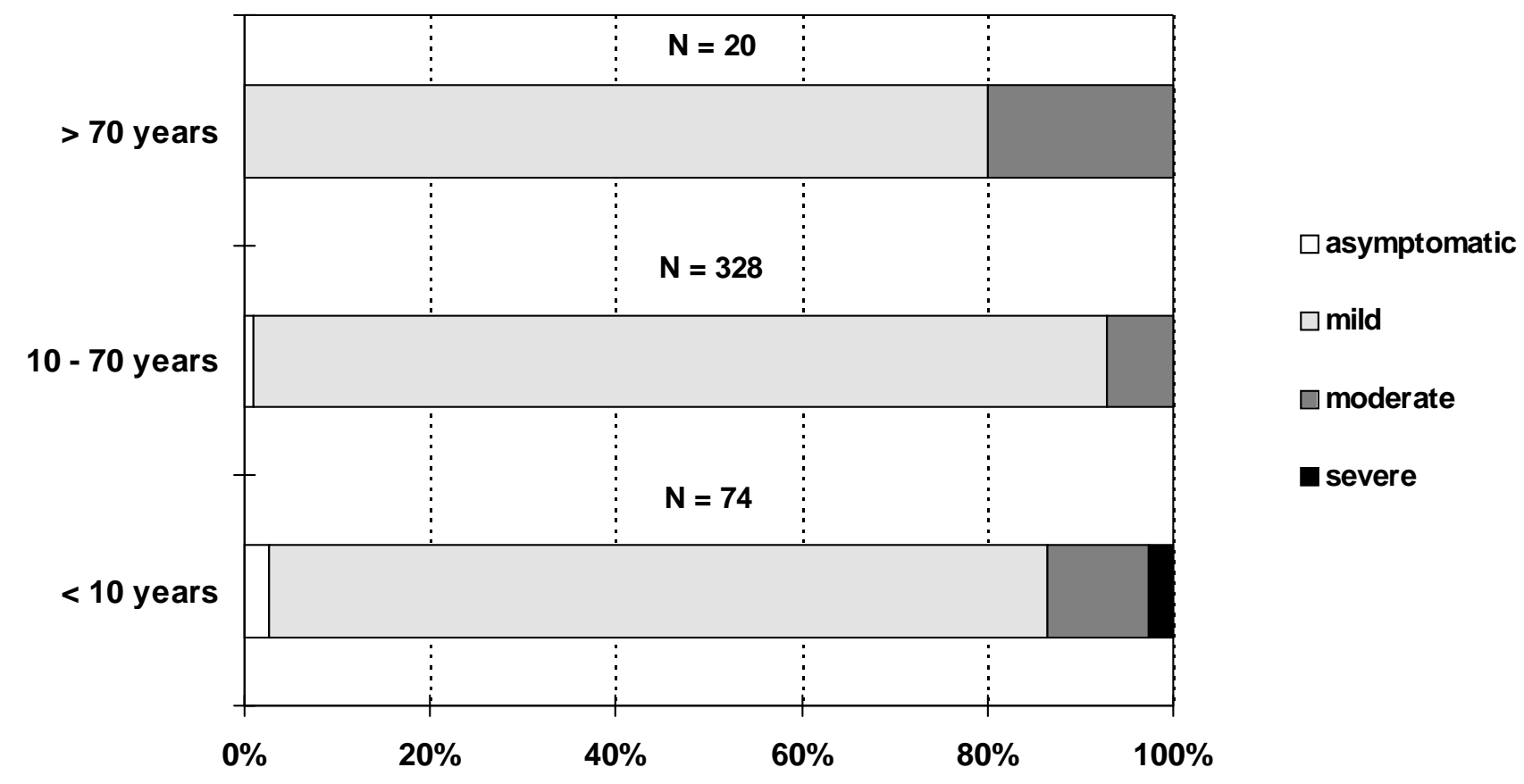

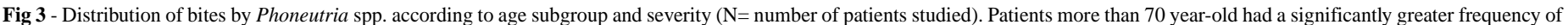
moderate envenomations compared to the 10-70-year-old individuals ( $\mathrm{p}=0.09$, chi-square and Fisher exact tests) 


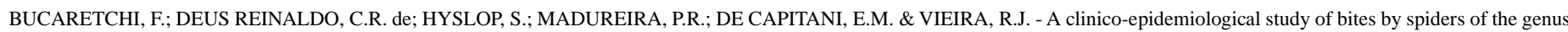
Phoneutria. Rev. Inst. Med. trop. S. Paulo, 42 (1): 17-21, 2000.

in the feet and hands. The low frequency $(1.2 \%)$ of asymptomatic cases agrees with the observations of VITAL-BRAZIL \& VELLARD (1926) that in certain situations these spiders may bite without injecting venom.

P. nigriventer venom activates and delays the inactivation of neuronal $\mathrm{Na}^{+}$channels ${ }^{8-9}$. This action may lead to the depolarization of muscle fibers and nerve terminals at the neuromuscular junction, as well as activation of the autonomic nervous system to cause the release of neurotransmitters, principally acetylcholine and catecholamines ${ }^{7,20}$. Peptides present in the venom of $P$. nigriventer can induce vascular smooth muscle contracture ${ }^{2}$ and can also increase vascular permeability ${ }^{1}$ by activating the tissue kallikrein system ${ }^{10,12}$ and stimulating the release of nitric oxide ${ }^{16}$. P. nigriventer venom also delays gastric emptying in rats, partly as a result of venom-induced catecholamine release ${ }^{5}$. The findings of the above studies may help to explain the local (pain and paresthesia $^{8,9,12}$ and edema ${ }^{1,12}$ ) and systemic (tachycardia ${ }^{7,20}$, vomiting ${ }^{5}$, priapism ${ }^{10,16}$ and shock $^{2,7,20}$ ) clinical manifestations seen following envenomation by Phoneutria spp. in our patients, perhaps through an increase in sympathetic activity in the more serious cases.

The greater frequency of moderate cases in old patients may reflect a lower tolerance to the autonomic disturbances triggered by the venom. That the only two severe cases of envenomation occurred in children less than 5 year-old suggest a dose-related effect based on the lower body surface area of these individuals. To date, ten deaths attributed to Phoneutria spp. have been reported in Brazil ${ }^{6,17-19}$, but in only two of these cases ${ }^{18}$ were sufficient details provided to allow comparison with the present series of patients.

In most patients, the common complaint of local pain was treated symptomatically, with good results. The low number of cases requiring antivenom therapy (2.3\%, mainly children with systemic manifestations) suggests that the criteria established for determining the need for antivenom ${ }^{13}$ are indeed adequate.

In conclusion, accidents involving the genus Phoneutria are common in the region of Campinas, with the highest risk groups being children under 10 years of age and adults over 70 years of age. Cases of serious envenomation are rare $(0.5 \%)$.

\section{RESUMO}

\section{Estudo clínico-epidemiológico dos acidentes causados por aranhas do gênero Phoneutria}

Foram estudados, de janeiro de 1984 a dezembro de 1996, 422 pacientes (9 meses-99 anos, mediana 29 anos), picados por aranhas capturadas e identificadas como Phoneutria spp. A maioria dos acidentes ocorreu nos meses de março e abril $(29,2 \%)$, dentro das residências (54,5\%), no período diurno (76,5\%) e nos membros (pés, $40,9 \%$ e mãos, $34,3 \%$ ). À admissão, a maioria dos pacientes apresentava somente queixas locais, principalmente dor $(92,1 \%)$ e edema $(33,1 \%)$, tendo sido classificados como acidentes leves $(89,8 \%)$, moderados $(8,5 \%)$, graves $(0,5 \%)$ e assintomáticos $(1,2 \%)$. Constatou-se que os acidentes classificados como moderados foram significativamente mais freqüentes nos pacientes com idade acima de 70 anos, quando comparados com o grupo etário de 10 a 70 anos $(\mathrm{p}<0,05)$ e que os 2 casos classificados como graves ocorreram em 2 crianças, respectivamente com 9 meses e 3 anos de idade, ambas desenvolvendo edema pulmonar agudo, evoluindo a segunda para o óbito, 9 horas após o acidente. Procedimentos para o alívio da dor foram amplamente utilizados (anestesia local - 32,0\%, anestesia local e analgésicos - 20,1\% e, analgesia via oral exclusiva $25,6 \%$ ). O antiveneno antiaracnídico foi empregado em 2,3\% dos casos ( 2 graves e 8 moderados, 8 destes crianças), não sendo observada nenhuma reação precoce ao antiveneno. Pode se concluir que apesar de os acidentes com aranhas do gênero Phoneutria serem comuns na região de Campinas, os acidentes graves são raros, sendo observados em somente $0,5 \%$ desta casuística, constituindo grupos de risco crianças com menos de 10 anos de idade e pacientes idosos (> 70 anos).

\section{ACKNOWLEDGEMENTS}

Cláudia Regina de Deus Reinaldo was the recipient of a scholarship from PIBIC/CNPq-PRP-UNICAMP (1997-1998). We also thank the medical staff of the Pediatric Intensive Care Unit, Hospital e Maternidade Celso Pierro, Pontifícia Universidade Católica de Campinas (PUCCAMP) and, Maria Teresa de Oliveira, of the Centro de Controle de Intoxicações-FCM-UNICAMP, for her technical assistance.

\section{REFERENCES}

1. ANTUNES, E.; MARANGONI, R.A.; BRAIN, S.D. \& DE NUCCI, G. - Phoneutria nigriventer (armed spider) venom induces increased vascular permeability in rat and rabbit skin in vivo. Toxicon, 30: 1011-1016, 1992.

2. ANTUNES, E.; MARANGONI, R.A.; BORGES, N.C.C.T. et al. - Effects of Phoneutria nigriventer venom on rabbit vascular smooth muscle. Braz. J. med. biol. Res., 26: 81-91, 1993.

3. BUCARETCHI, F. - Análise das principais diferenças clínicas e epidemiológicas dos acidentes por escorpiões das espécies Tityus serrulatus e Tityus bahiensis, e por aranhas do gênero Phoneutria, atendidos no CCI-HC-UNICAMP, no período de janeiro de 1984 a julho de 1988. Campinas, 1990. (Dissertação de Mestrado Faculdade de Ciências Médicas da Universidade Estadual de Campinas).

4. BUCARETCHI, F. - Acidentes por Phoneutria. In: SCHVARTSMAN, S., ed. Plantas venenosas e animais peçonhentos. São Paulo, Sarvier, 1992. p. 196-201.

5. BUCARETCHI, F. \& COLLARES, E.F. - Effect of Phoneutria nigriventer spider venom on gastric emptying in rats. Braz. J. med. biol. Res., 29: 205-211, 1996.

6. BÜCHERL, W. - A “armadeira”: a aranha mais perigosa do mundo! In: BÜCHERL, W., ed. Acúleos que matam. Rio de Janeiro, Kosmos, 1985. p. 35-45.

7. COSTA, S.K.P.; MORENO, J.R.H.; BRAIN, S.D. et al. - The effect of Phoneutria nigriventer (armed spider) venom on arterial blood pressure of anaesthetised rats. Europ. J. Pharmacol., 298: 113-120, 1996.

8. CRUZ-HOFLING, M.A.; LOVE, S.; BROOK, G. \& DUCHEN, L.W. - Effects of Phoneutria nigriventer spider venom on mouse peripheral nerve. Quart. J. exp. Physiol., 70: 623-640, 1985.

9. FONTANA, M.D. \& VITAL-BRAZIL, O. - Mode of action of Phoneutria nigriventer spider venom at the isolated phrenic nerve-diaphragm of the rat. Braz. J. med. biol. Res., 18: 557-565, 1985.

10. LOPES-MARTINS, R.A.B.; ANTUNES E.; OLIVA, M.L.V. et al. - Pharmacological characterization of rabbit corpus cavernosum relaxation mediated by the tissue kallikrein-kinin system. Brit. J. Pharmacol., 113: 81-86, 1994.

11. LUCAS, M.S. - Spiders in Brazil. Toxicon, 26: 759-772, 1988 
12. MARANGONI, R.A.; ANTUNES, E.; BRAIN, S.D. \& DE-NUCCI, G. - Activation by Phoneutria nigriventer (armed spider) venom of the tissue kallikrein-kininogen-kinin system in rabbit skin in vivo. Brit. J. Pharmacol., 109: 539-543, 1993.

13. BRASIL. MINISTÉRIO DA SAÚDE. FUNDAÇÃO NACIONAL DA SAÚDE Acidentes por Phoneutria. In: Manual de diagnóstico e tratamento de acidentes por animais peçonhentos. Brasília, Ministério da Saúde/Fundação Nacional da Saúde, 1998. p. 54-56.

14. BRASIL. MINISTÉRIO DA SAÚDE. FUNDAÇÃO NACIONAL DA SAÚDE Araneísmo. In: Manual de diagnóstico e tratamento de acidentes por animais peçonhentos. Brasília, Ministério da Saúde/Fundação Nacional da Saúde, 1998. p. 49-53.

15. RAMOS, E.F.; ALMEIDA, C.E.; GOUVÊA, E. \& CARMO-SILVA, M. - Considerações sobre a atividade de locomoção, preferência por ecótopos e aspectos territoriais de Phoneutria nigriventer (Keiserling, 1891), (Aranae, Ctenidae). Rev. bras. Biol., 58: 71-78, 1998.
16. REGO, E.; BENTO, A.C.; LOPES-MARTINS, A.B. et al. - Isolation and partial characterization of a polypeptide from Phoneutria nigriventer spider venom that relaxes rabbit corpus cavernosum in vitro. Toxicon, 34: 1141-1147, 1996.

17. ROSENFELD, G. - Animais peçonhentos e tóxicos do Brasil. In: LACAZ, C.S.; BARUZZI, R.G. \& SIQUEIRA Jr., W., ed. Introdução à geografia médica do Brasil. São Paulo, EDUSP, 1972. p. 430-475.

18. VELLARD, J. - Les araignées vraies. Les ctènes. In: VELLARD, J., ed. Le venin des araignèes. Monographies de L'Institut Pasteur. Paris, Masson, 1936. p. 169-184.

19. VITAL-BRAZIL \& VELLARD, J. - Contribuição ao estudo do veneno das aranhas. II Mem. Inst. Butantan, 2: 3-77, 1926.

20. VITAL-BRAZIL, O.; BERNARDO-LEITE, G.B. \& FONTANA, M.D. - Modo de ação da peçonha da aranha armadeira, Phoneutria nigriventer (Keiserling, 1891), nas aurículas isoladas de cobaia. Ciênc. Cult., 40: 181-185, 1988.

Received: 22 April 1999

Accepted: 03 January 2000 


\section{SUMMARY OF THESIS}

SZTAJNBOK, Sérgio - Impacto da qualidade de água na doença diarréica aguda em dois bairros do município de Taboão da Serra. São Paulo, 1999.

(Dissertação de Mestrado - Faculdade de Medicina da Universidade de São Paulo).

\section{IMPACT OF WATER QUALITY IN ACUTE DIARRHEA IN TWO DIFFERENT NEIGHBORHOODS INTHE MUNICIPALITY OF TABOÃO DA SERRA}

Acute diarrhea (AD) is an important infant morbidity-mortality cause in developing countries. It is estimated that 1.3 billion annual episodes of diarrhea are observed in children younger than 5 years of age, and are the cause of 4 million deaths. In the last two decades, several studies have reported the relevance of social-economic and environmental factors in the genesis of AD. Unfortunately, despite the vast knowledge and governmental measures to assure acceptable basic sanitation conditions for the population, the problem has not been appropriately solved. This is observed in the municipality of Taboão da Serra, in the neighborhood of Sílvio Sampaio. Because it is far from downtown, is suffers from frequent supply pressures by SABESP, and is therefore known by the technical term of "end of net". This makes water supply intermittent and forces the population of the neighborhood to search for alternative water sources (wells and springs) every other day. To correlate water quality and frequency of Acute Diarrhea, AD cases seen throughout 1996 in two health centers in two different neighborhoods in Taboão da Serra were evaluated: Local Health Unit (LHU) Sílvio Sampaio, located in the neighborhood of Sílvio Sampaio, the previously mentioned "end of net" neighborhood and LHU Taboão da Serra, located in the a downtown neighborhood which is not affected by intermittent supply. The number of patients seen for AD in LHU Sílvio Sampaio was four times greater, a statistically significant difference $(\mathrm{p}<0,001)$. In addition, the water quality of the alternative sources used by the Sílvio Sampaio population was evaluated ( 7 samples from wells and springs), by microbiologic evaluation carried out by CETESB, according to the rules established by the Health Ministry. Of the seven samples, only one was considered potable for human consumption, however the amount of heterotrophic bacteria in this sample was within the upper normal range established by the above mentioned rules. To evaluate other relevant factors in the genesis of acute diarrhea according to literature, the socialeconomic profile of the studied populations was established and a statistical difference was observed in some parameters: the numbers of rooms in the downtown households was greater in the Sílvio Sampaio neighborhood; the number of individuals per room was greater in the Sílvio Sampaio neighborhood; per capita income in the downtown neighborhood was approximately $70 \%$ greater than in the Sílvio Sampaio neighborhood, the parents of the children in the downtown neighborhood had a higher education level than those in the Sílvio Sampaio neighborhood and finally, the number of homes provided with a sewage system was significantly higher in the downtown neighborhood. Therefore, it was concluded that the data above does not allow a correlation of water quality alone with the higher number of AD observed in the Sílvio Sampaio neighborhood, once other environmental and classical AD-related factors had a statistically significant difference as well. However, the influence of water quality in the genesis of acute diarrhea is clear, and supports the need of Public Health interventions to improve water supply in the neighborhood and stimulate educational programs, showing the population the risks related to the use of alternative sources. 